\title{
The S-CORE Teaching Mode Conducted in the Basic Courses in Higher Vocational Education
}

\author{
Shenghua Zhang \\ General Platform Department \\ Beijing Information Technology College \\ Beijing, China 100016
}

\author{
Lu Sun \\ General Platform Department \\ Beijing Information Technology College \\ Beijing, China 100016
}

\begin{abstract}
Higher vocational education has long been confronted with the problem of low teaching efficiency caused by the less-motivated students and the low involvement in class. In order to cope with this problem, based on the relevant research, Beijing Information Technology College constructed the S-CORE teaching mode. Under the guide of "studentcentered" philosophy, the S-CORE teaching mode aims to make the courses more attractive and the class more efficient. In this paper, the authors discuss the theoretical basis of $\mathrm{S}$ CORE, how to construct the mode and how to conduct the mode. What's more, the authors sum up the innovation features and applications in the process of teaching reform and research.
\end{abstract}

Keywords-student-centered; teaching mode; outcome-based; competency-based; empathy-based; research-based

\section{INTRODUCTION}

With the development of China's economy into the New Normal era, the strategy of revitalizing China through talented persons becomes more and more significant. Higher vocational education facing so many new challenges and chances should adjust its educational objectives accordingly. Whether the educational objectives can be achieved and whether the educational quality can be guaranteed mainly depends on the quality of each courses and the quality of each class. By analyzing the relevant data, many researchers have discovered that the result of the teaching reform is not as efficient as expected and the teaching quality (especially the basic courses) has been declining. The reasons are complicated and one of the most important ones is that although the teachers can accept the "student-centered" teaching philosophy, the teachers do not know to apply the philosophy to their teaching reform. In the new era, the students who have grown up with the accompany of electronic equipment rely too much on cell phones, pad, etc. Teachers should gasp the method to stimulate the students to take part in the class activities actively and to improve the learning effects.

\section{THE CONNOTATION OF S-CORE TEACHING Mode}

Aiming at improving teaching quality and the teaching efficiency, Beijing Information Technology College initiated a project. After three-year research and application, this project has achieved the goal of constructing a teaching mode which is suitable for the basic courses in higher vocational education and which can improve both the teaching quality and the teaching efficiency. The mode is the S-CORE teaching mode. Referring to previous research, considering the practical situation of higher vocational education in China, this project strives to probe the problem from theoretical aspect as well as practical aspect and puts the research outcome into practice.

\section{A. Defining S-CORE Teaching Mode}

Under the guide of "student-centered" teaching philosophy, the S-CORE combines the "Competency-based, Outcome-based, Research-based" educational theories and Empathy-based design theory. "S" stands for Studentcentered, which is the basis for all designs involved in the teaching activities. "C" stands for Competency-based, which means that the objectives of the courses or curriculum are to improve the students' general competencies, which are very important for their long life after school, especially, for their future career. "O" stands for Outcome-based, which means that courses, activities, and assessments should all help students achieve the specified outcomes. The focus on outcomes creates a clear expectation of what needs to be accomplished by the end of the course. "R" stands for Research-based, which means students should be responsible for their learning and the whole learning process is a selfmotivated research journey. "E" stands for Empathy-based, which means teachers who design the courses or class activities should use the empathy principle to get a deep understanding of what the students really care about, really need, really worry about, etc.

"Student-centered" teaching philosophy has a long history in both China and other countries and is widely spread and accepted. This project develops the core ideas of "student-centered" philosophy and adopts the constructionism which advocates student-centered, discovery learning where students use information they already know to acquire more knowledge. In this project, the courses and classes are designed from the students' angle, the students are supported to feel that they have the power to deal with the problem and are encouraged to discover, analyze and solve the problems. Empathy is the capacity to understand or feel what another person is experiencing from within the other person's frame of reference i.e., the capacity to place oneself in another's position. In Design Thinking, which is a 
human-centered design ethos, designers approach users with empathy, by this way, they can understand what people really need. Similarly, when we design the courses, the class activities and make the relevant teaching materials, we can use the Empathy Principle used in Design Thinking to get the deep insight of the students' real need.

What's more, the S-CORE involves the four pillars of education in the 21 st century (Learning to know, Learning to do, Learning to live together, Learning to be) promoted by UNESCO and absorbs the Competency-based Education philosophy to conduct the basic courses teaching reforms in higher vocational colleges.

Meanwhile, the whole teaching process is treated as a system in which the elements influenced by each other and the system is self-adapting and growing and can adjust itself with its environment. In contrast to traditional teaching mode, S-CORE teaching mode aims to encourage increased student involvement in the class activities, and by actively taking part in the meaningful and high-impact class activities, the students can construct their knowledge, skills and competencies and achieve the learning objectives as shown in "Fig. 1".

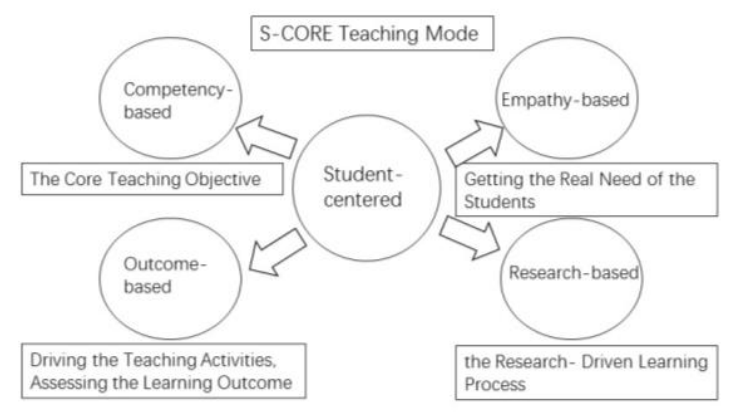

Fig. 1. S-CORE teaching mode.

\section{B. The Implementation of S-CORE Teaching Mode}

1) Setting the teaching objectives: For the S-CORE teaching mode, the teaching objective is that by motivating the students to accomplish the well-designed, meaningful and high-impact learning activities, such as group works, research projects, class discussions, etc., the teacher provokes and facilitates the students to reflect on and construct their understanding of what they are learning. By the end of the learning activities, each student should have produced the expected outcome and achieved the goal. In this process, the students can develop their general competencies, for instance, communication skills, cooperation and collaboration skills, problem-solving ability and self-learning ability, etc.

The key point is that the teacher should use the Empathy principle in Design Thinking and design the courses according to the insight of the students' real need and feeling.

2) Designing the teaching plan: Designing the teaching plan is a key part of S-CORE. The design is outcome-based.
- Designing the induction part. In this part, the teacher should design a question, a task, or create a situation. They are related with the knowledge to be learned or the skills or to the competencies be trained. Students are encouraged to understand the question, the task and to immerse in the created situation.

- Designing the body part. In this part, by designing a series of interactive activities such as searching for information, case analyzing, research exploration, discussion, presentation, experiment, etc., the teacher stimulates the students to be actively involved. In the process of deep involvement in the activities, the students can construct their primary understanding of the problems. Then, the teacher guides the students to analyze the problems from outside to the inside, from superficies to interior, from concrete to abstract and arrive at the solutions to the problems.

- Designing the assessment part. The assessment is formative and outcome-based. According to the expected outcome, the teacher designs the task-based instruction manual, which serves as the detail record of the learning process. The students and the teacher can assess the learning outcome according to the record.

3) Implementing the teaching plan: Let's take Applied Mathematics as an example. In the class, the teacher puts forward a real problem (or task), and by searching for the solution to the problem, the students construct the knowledge of function and the calculus.

In the induction part, the teacher designs a task that comes from the real life or a problem in connection with their major. This task should arouse the interest of the students. In the body part, the first class activity is group discussion in which group research is encouraged. By analyzing the task, the students may meet some difficulties and have some questions in their mind. The teacher will grasp this opportunity, introduce the relevant calculus, and provide some other examples for the students. The teacher guides the students to find the regularity and connect the knowledge with previously learnt knowledge. After that, the students are asked to solve some similar problems in their real life, which serves to consolidate their understanding of the calculus. Finally, the teacher comes to the original task and summarizes the relevant calculus knowledge. In the assessment part, according to the detailed record of the research process, problem solving, knowledge learning, made on the instruction manual, the teacher and the students conduct teacher assessment and the peer assessment.

4) Feedback: S-CORE teaching mode is an open system, in which students, teacher, teaching contents, teaching methods, teaching resources and tools interact with each other. During this process, new problems and new requirements will pop up. Referring to PDCA (Plan, Do, Check and Act) method, the teaching process is dynamic and the teacher should reflect on the whole process and improve the whole process continually. S-CORE teaching process is shown in the following "Fig. 2". 


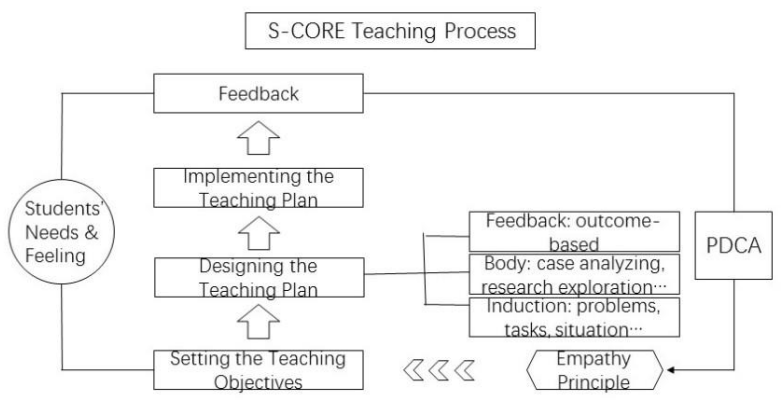

Fig. 2. S-CORE teaching process.

\section{Constructing the Teaching Resource Correlated with the $S$-CORE Teaching Mode}

In order to ensure that we can implement the S-CORE teaching mode smoothly, we need to construct plenty of teaching resources, which can help the students to carry out the research-based and competency-based learning.

\section{THE INNOVATION FEATURES OF S-CORE TEACHING MODE}

- S-CORE teaching mode incorporates the advantages of several educational theories. It is student-centered and competency-based. Under this teaching mode, the teaching efficiency can be increased. The students become more motivated and more active.

- When design the S-CORE teaching mode, we use "two lines". To achieve the knowledge objective and the competency objective is "implied line". To finish the task or to solve the problem is the "overt" line. The two lines run through the entire teaching process. The "overt" line can arouse the students' interest and motivation and help them achieve the knowledge objective and competency objective.

- The S-CORE teaching mode treats the whole teaching process as a system in which the elements (the students, the teacher, the teaching resources and methods) influence each other. It is an open and dynamic system.

- The S-CORE adopts the iteration theory and the teaching process can adjust itself according to the environment. There are so many uncertainties in the input process (the knowledge, the teaching resources) and the output process (the outcome) that the teaching objective, the teaching methods, etc. should change accordingly.

- The S-CORE is empathy-based. We use the Empathy Principle to get the deep insight of the students' real need, which is important to determine the teaching objective and teaching plan.

\section{THE APPLICATION VALUE OF S-CORE TEACHING MODE}

When constructing the S-CORE teaching mode, we applied it in the basic courses in higher vocational college. We use the S-CORE teaching mode to determine the teaching objective, design the teaching plan and construct the relevant teaching resources. The courses designed by this way enjoy a high popularity among the students.

Summarizing the successful approaches, we think the SCORE teaching mode is of application value.

- The Empathy Principle can help us to identify the real need of the students and can sort out the needs of different students.

- The open and dynamic teaching system can continually change, absorb and recycle according to the environment.

- Outcome-based teaching design makes the whole teaching process more clear about the outcome. The definition of outcome is broad.

\section{CONCLUSION}

The S-CORE teaching mode adopts the iteration theory and the PDCA theory, so the improvement is continuous. So long as the variables in the environment change, the SCORE teaching system will change.

In addition, there are some problems needing to be solved. For example, the S-CORE teaching mode cannot cope with the differences of each student. The teaching design cannot change with the environment simultaneously. So there is still room for improvement to deepen our research.

\section{REFERENCES}

[1] Alesandrini, K. \& Larson, L, Teachers bridge to constructivism. The Clearing House, 2002, pp. 119-121.

[2] Bellet, Paul S. and Michael J, "The importance of empathy as an interviewing skill in medicine". JAMA, 1991, 226 (13), pp. 18311832.

[3] Butler, Mollie, Outcomes Based/ Outcomes Focused Education Overview, 2004

[4] Laffey, J., Tupper, T., Musser, D., and Wedman, J., "A computermediated support system for project-based learning". Paper presented at the annual conference of the American Educational Research Association, Chicago, IL, 1997.

[5] Feng Qihong, Yang Hui, Ma Jianshan, and Jin Yujie, "Studentcentered Curriculum Refrom and Application". China University Teaching, 2017(10), pp. 68-71.

[6] Li Man, "Research on Student-centered Informationized Teaching Mode". China University Teaching, 2012(08), pp. 32-36.

[7] He Xiaoyan, Huang Lei and Cao Junxing, "On Teaching Quality Improvement Strategies of Basic Courses of Majors of Science and Engineering". Heilongjiang Researches on Higher Education, 2017(08), pp. 158-162.

[8] Spady, William, Outcome-Based Education: Critical Isues and Answers, Arlington Virginia: American Association of School Administrators, 2014 
[9] Wilson, B., Constructivist learning environments: Case studies in instrumental design, Englewood Cliffs, NJ: Educational Technology Publications. 